\title{
Simulation of deposit parameters in underground development mining
}

\author{
Vladimir Golik ${ }^{1}$, Yuriy Razorenov ${ }^{2}$, Volodymyr Morkun ${ }^{3 *}$, and Nataliia Morkun ${ }^{3}$ \\ ${ }^{1}$ North Caucasus Mining Metallurgical Institute, 85 Pobedy St., 308015 Vladikavkaz, Russia \\ ${ }^{2}$ South Russian State Polytechnic University, 132 Prosveshcheniya St., 346428 Novocherkassk, Russia \\ ${ }^{3}$ Kryvyi Rih National University, 11 Vitaliia Matusevycha St., 50027 Kryvyi Rih, Ukraine
}

\begin{abstract}
The article is aimed at improving development mining to prepare an ore body for stoping by access ramps to provide comfortable conditions and high technical and economic indices in underground mining. Efficient parameters of underground mining are chosen in the course of simulating data on the mining theory and practice considering ore losses and dilution on the basis of critical analysis of uranium mining enterprises' activities. The research provides data on geological and engineering zoning of an ore deposit and physical-mechanical properties of ore bearing rocks. The advanced experience is systemized and there is provided system analysis of modern development mining schemes with access ramps (ring, spiral, one-way inclined, central inclined and across the strike). The research recommends schemes of development mining and substantiates their advantages. There are quantitative indices of physical simulation of development variants as to drawn ore quality according to criteria of soil location in ore draw points. The scientific novelty implies developing the criterion of optimality and ranking variants of development mining according to technical-economic and geomechanical indices considering some technological factors as well as the number of stopes operating simultaneously on the level. The study consists in increasing authenticity of development projects through applying complex schemes of access ramps according to the complex criterion of increasing mining depths, equipment application, ventilation and underground mine capacity.
\end{abstract}

\section{Introduction}

Conditions of deposit localization and mining often affect efficiency indices. They can be taken into account while designing deposit mining [1 - 4].

High mining efficiency and relatively small amounts of development and face-entry operations accompanied by complex mechanization of operations cause high ore losses and dilution of some mining variants.

Along with undisputable advantages of certain development variants, first of all, due to reduced amounts of excavation, they are characterized by high ore losses and dilution $[5,6]$.

Repeated fragmentation is observed in the drawn ore that has an impact on ore losses and dilution in mining. Computational methods used to determine development mining

\footnotetext{
* Corresponding author: morkunv@gmail.com
} 
parameters allow some discrepancies in setting quality indices. Ore losses and dilution can be determined directly only during the operation stage.

With increasing the stoping depth at most ore deposits, mining and geological conditions such as the ore body thickness, the dip angle and forms of rock pressure manifestation change.

To maintain the designed capacity of a deposit and achieved labour efficiency there arises a necessity to improve parameters of development mining before stoping.

For the most widely used development schemes through access ramps and sublevel drifts under changing mining-geological conditions, the amount of development and faceentry operations increases greatly reaching $80 \%$ of the total.

Improvement of development schemes implies increased rates of increasing stoping depths, application of mobile equipment, provision of stope ventilation and increased mine capacity $[7-9]$.

\section{Materials and methods}

The research aim is achieved through applying methods of analyzing the ore mining theory and practice and simulating enterprises' mining indices.

Through application of a complex method, the authors develop the optimality criterion serving the basis for ranking development variants considering technological factors allowing them to increase authenticity of development mining projects with access ramps.

To develop recommendations on choosing efficient development schemes, geological and engineering ore zoning is performed.

Any operating mining enterprise and coal mine in particular, represent the difficult dynamic system that functioning in continuously changing conditions of the internal and external environment.

\section{Results}

Horizontal rock movements at the distance of $30 \mathrm{~m}$ from the deposit are conditioned by rock subsidence of the hanging wall over the stoping zone. Vertical rock movements are influenced upon by stoping operations. Table 2 presents physical and mechanical properties of rocks.

Table 1. Basic properties of ore-bearing rocks.

\begin{tabular}{|l|c|c|c|c|c|c|c|}
\hline Rocks & $\begin{array}{c}\text { Density, } \\
1 \times 10^{-3}, \\
\mathrm{~g} / \mathrm{m}^{3}\end{array}$ & $\begin{array}{c}\text { Compression } \\
\text { strength, } \\
\mathrm{MPa}\end{array}$ & $\begin{array}{c}\text { Internal } \\
\text { friction } \\
\text { angle, } \\
\text { degree }\end{array}$ & $\begin{array}{c}\text { Longitudinal } \\
\text { wave } \\
\text { velocity, } \\
\mathrm{m} / \mathrm{sec}\end{array}$ & $\begin{array}{c}\text { Transverse } \\
\text { wave } \\
\text { velocity, } \\
\mathrm{m} / \mathrm{sec}\end{array}$ & $\begin{array}{c}\text { Acoustic } \\
\text { stiffness, } \\
1 \times 10^{6}, \\
\mathrm{~kg} / \mathrm{m}^{2} \mathrm{sec}\end{array}$ & $\begin{array}{c}\text { Poisson } \\
\text { ratio }\end{array}$ \\
\hline $\begin{array}{l}\text { Quartz } \\
\text { porphyry }\end{array}$ & 2.76 & 152.6 & 59 & 4440 & 2630 & 12.1 & 0.22 \\
\hline Conglomerate & 2.85 & 98.3 & 53 & 4210 & 2490 & 12.0 & 0.22 \\
\hline Interstratified & 2.86 & 143.8 & 58 & 4690 & 2700 & 13.3 & 0.25 \\
\hline Rocks & 2.86 & 102.0 & 56 & 4550 & 2580 & 13,0 & 0.26 \\
\hline
\end{tabular}

In the ring-type scheme of mining development, level drifts are located either within the ore body or in the hanging and footwall rocks. The disadvantages of the variants include low ore stability and increased amounts of development mining.

With LHD machines, the haulage length is $50-60 \mathrm{~m}$.

The distance between stope ore passes is:

$$
l_{\text {ore }}=l_{\text {del }}-l_{\text {flt }}=50-20=30 \mathrm{~m} \text {, }
$$


where $l_{\text {ore }}$ is the distance between ore passes, $\mathrm{m} ; l_{\text {del }}$ is the haulage distance, $\mathrm{m}$; $l_{f l t}$ is remoteness of ore passes from the fault zone, $\mathrm{m}$.

In case of development mining with ramps in the deposit centre, sublevel drifts are replaced with ore drifts. Ore is mined from flanks to the centre towards the ramp with two stopes per a level simultaneously (Fig. 1).

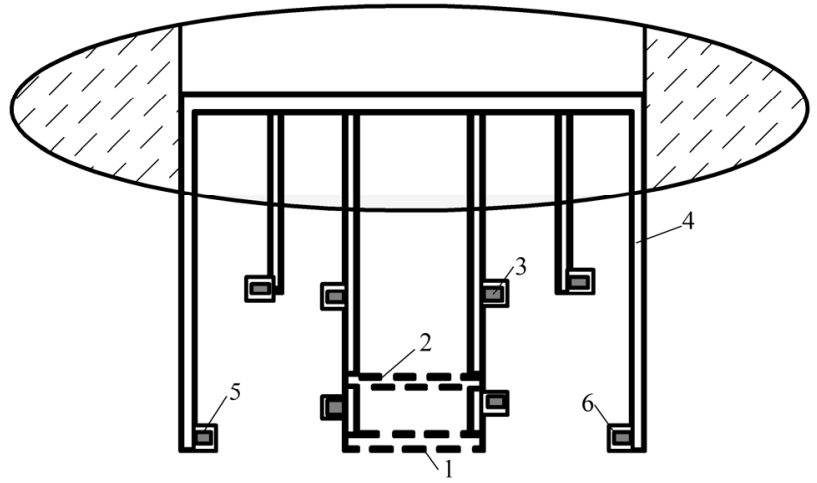

Fig. 1. Development mining of a level with an access ramp in the centre: 1 - inclined mine working of a ramp; 2 - horizontal mine working; 3 - haulage sublevel ort; 4 - ventilation-haulage ort; 5 - ore pass; 6 - raise.

As to mine working localization, an access ramp can be spiral and one-way. The spiral ramp is characterized by a smaller drifting capacity as compared to the one-way one.

The spiral ramp length is:

$$
L_{\text {inc }}=\left(\frac{h_{S S}}{\sin \alpha}+l_{r}\right) n
$$

where $L_{\text {inc }}$ is the ramp working length; $h_{s s}$ is a sublevel height; $\alpha$ is a slope angle; $l_{r}$ is the curve length between road turns; $n$ is the number of sublevels.

The one-way ramp length is:

$$
L_{\text {inc }}=\left(\frac{h_{s s}}{\sin \alpha}+l_{r}\right) n+3 L_{h o r}
$$

where $L_{h o r}$ is the length of the ramp drift on a sublevel, m.

$$
l_{\text {hor }}=\frac{h_{S s}}{\operatorname{tg} \alpha}=\frac{12.5}{\operatorname{tg} \alpha}=71 .
$$

The disadvantage of the spiral ramp location parallel to the strike consists in the fact that the final mining point on sublevels increases making operations less flexible.

The one-way ramp does not have this disadvantage, yet, it is characterized by increased amounts of drifting. The spiral ramp with extra drifting on a sublevel is characterized by minimum production costs. Two sublevels are driven towards the ramp, and one sublevel is driven to the mine working connecting the deposit centre and the ramp.

The length of the spiral ramp with a horizontal drift on the sublevel is:

$$
L_{\text {inc }}=\left(\frac{h_{S S}}{\sin \alpha}+l_{r}\right) n+3 L_{h o r} .
$$

Development mining with a ramp in the centre increases the development duration and makes control of rock pressure more complicated (Fig. 2). 

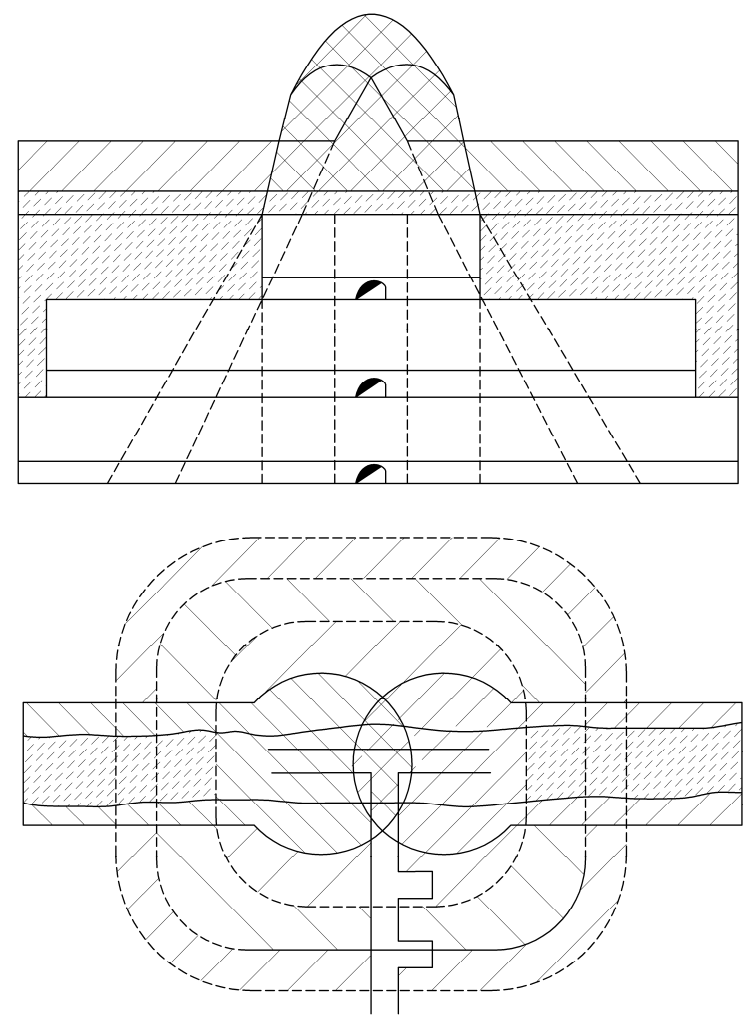

Fig. 2. Distribution diagrams of increased rock pressure in the vicinity of an access ramp.

As to rock pressure control, it is more efficient to mine an ore deposit from the centre to flanks, although this increases the number of development workings because of an extra access ramp.

There is no need to increase the length of a haulage drift of the main level if an access ramp is across the strike.

When a level is developed with two access ramps, extra haulage drifts cannot be used. For unidirectional inclined workings on the flanks, drifts connecting ramps are along the ore, while those connecting orts are used for ventilation and ore haulage.

Development mining variants with access ramps increase the development duration and limit the number of stopes functioning simultaneously on a level.

To avoid these drawbacks access ramps are located at the distance of a quarter of an ore body length from the body flanks (Fig. 3).

Per each ramp in 16 stopes, increased intensity of level driving reduces the time for drift presence in the zone of rock pressure development.

In level driving with three access ramps in the centre and on the flanks at the distance of $1 / 6$ of the body length, drifts are driven to each ramp on both flanks simultaneously with up 24 faces. The duration of level drifting and working maintenance costs decrease (Table 3).

Counter-stope mining onto a ramp is characterized by the fact that stress values rise to up to dangerous levels at the final stage of mining operations.

Centre-to-flanks or flank-to-flank stoping variants are reasonable if haulage units are focused at the ore body flanks.

Considering stope ventilation, decreased distances of ore haulage and collapse prevention, ore passes should be located at the hanging wall $5-10 \mathrm{~m}$ off the ore body. 

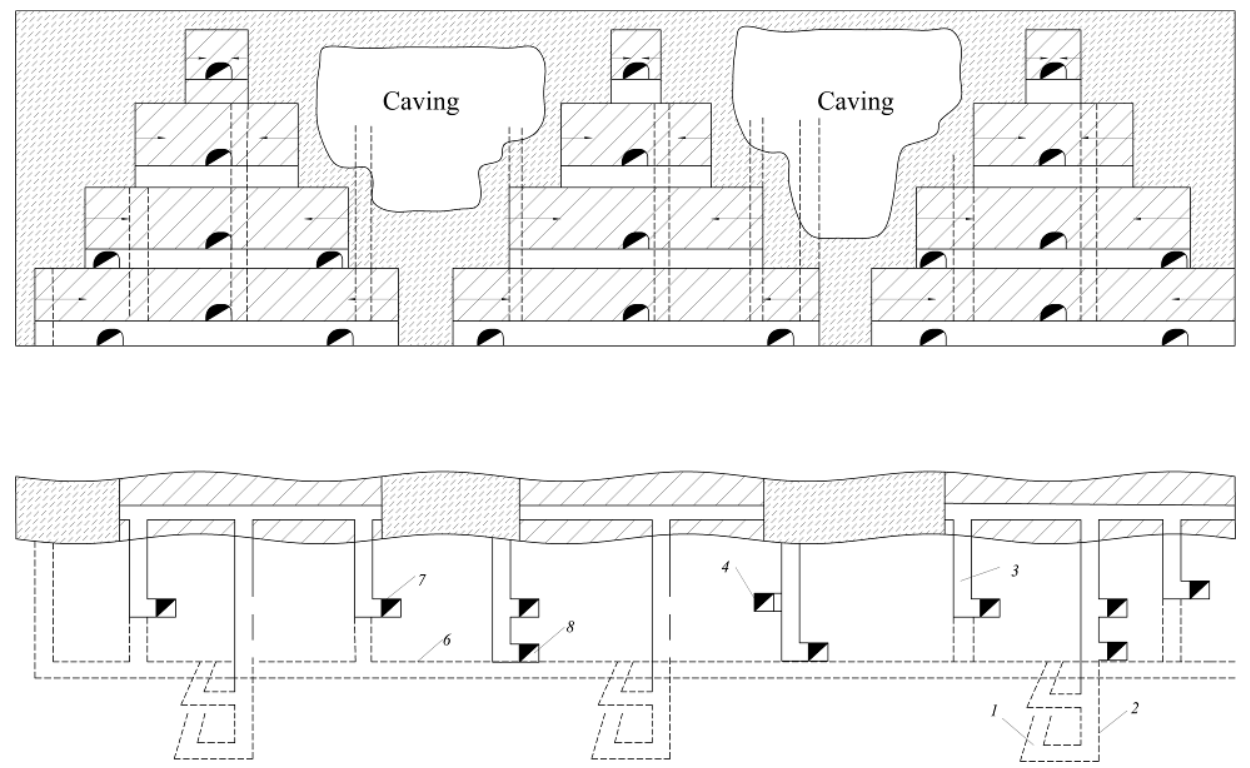

Fig. 3. Level development with three ramps: 1 -inclined drift; 2 -horizontal drift; 3 -haulage sublevel ort; 4 - ventilation-haulage ort; 5 -haulage crosscut of the main level; 6 - haulage drift of the main level; 7 - ore pass; 8 - raise.

Table 3. Drifting amount in access ramp development, $\mathrm{m}^{3}$.

\begin{tabular}{|l|c|c|c|c|}
\hline \multirow{2}{*}{ Mine workings } & \multicolumn{3}{|c|}{ Access ramp position as to the ore body } \\
\cline { 2 - 4 } & centre & flanks & $\begin{array}{c}\text { centre and } \\
\text { flanks }\end{array}$ & \multirow{2}{*}{ optimal } \\
\hline Inclined & 2450 & 4900 & 7340 & \multirow{2}{*}{2200} \\
\hline Horizontal & 340 & 680 & 1020 & \\
\hline Breakthrough & $160-800$ & 1600 & 2400 & 1300 \\
\hline Haulage orts & $2280-3360$ & $2240-3500$ & $2240-2280$ & 2280 \\
\hline Ventilation-haulage orts & 43004800 & $3800-4300$ & 2160 & - \\
\hline Haulage crosscuts & 3600 & $2160-3360$ & 2640 & 3020 \\
\hline Haulage drifts & 3880 & $3880-5600$ & 3800 & 4840 \\
\hline Ore passes & 3040 & $234-3740$ & 2100 & 2340 \\
\hline Raises & $2720-3180$ & $2730-3640$ & 2730 & 2130 \\
\hline Sublevel drift breakthrough & - & 1920 & - & 1750 \\
\hline Sublevel drifts & - & - & - & 15800 \\
\hline Total workings, $\mathrm{m}^{3}$ & $25140-26800$ & $25100-32400$ & 27200 & 39800 \\
\hline Ore, $\mathrm{m}^{3} / 1000 \mathrm{~m}^{3}$ rocks & $111-125$ & $14-117$ & 127 & 185 \\
\hline
\end{tabular}

All the variants do not use development operations at the footwall, a loop-haulage system on main levels and the increased sublevel height $(12.5 \mathrm{~m})$. The variants differ in stoping directions and the number of access ramps.

The following development schemes are recommended:

- one access ramp between ore bodies at the flank and a hoister on the other flank to develop centre-to-flank stoping;

- one access ramp between ore bodies to develop flank-to-flank stoping;

- two hoisters at both flanks.

In case of inclined sublevel caving and abut ore drawing, sublevel inclined drifts are both haulage and face-entry. 
In sublevel mining, concentration of operations increases. If the slope angle is 10 in inclined drifting, the number of workings increases (9 against 6).

With the equal number of sublevels, the developed height of the ore body reduces by 1.5 times, ore drawing conditions improve due to the reduced influence of the working abut and natural drainage occurs.

The efficiency of caving is determined by the quantity of ore losses and dilution [10 - 12].

The dependency of ore losses and dilution on the slope angle of the mine working has been investigated.

To simulate the process, crushed ore of $0+6 \mathrm{~mm}$ was used, the particle size taken geometrically similar to the actual one at a scale of 1:50. Overlying rocks are crushed $5-$ $10 \mathrm{~mm}$ rocks. The block model of $160 \times 160 \times 300 \mathrm{~mm}$ enabled us to change the slope angle of a mine working. $0^{\circ}, 5^{\circ}, 10^{\circ}$ working models were studied. Each series was performed three times.

To investigate the ore drawing quality with changing slope angles of a stope as to the $10^{\circ}$ mine working, there were simulated $90^{\circ}, 100^{\circ}$ and $110^{\circ}$ variants. In the model, the ore was covered by first two layers $80 \mathrm{~cm}$ thick and the third one $40 \mathrm{~cm}$ thick. On the surface of each layer, there were marks to form an ore drawing figure. The ore was drawn in portions of $200 \mathrm{~g}$. Each portion was bolted to determine dilution values. The ore drawing was over when dilution reached $75 \%$ (Table 4 ).

Table 4. Ore drawing simulation results.

\begin{tabular}{|c|c|c|c|c|c|c|c|}
\hline \multirow[b]{2}{*}{ Caving step } & \multicolumn{3}{|c|}{ Horizontal drift } & \multicolumn{2}{|c|}{$5^{\circ}$ draw point } & \multicolumn{2}{|c|}{$10^{\circ}$ draw point } \\
\hline & lot number & $\begin{array}{c}\text { rock } \\
\text { weight, } g\end{array}$ & $\begin{array}{c}\text { ore } \\
\text { weight, } g\end{array}$ & $\begin{array}{c}\text { rock } \\
\text { weight, } g\end{array}$ & $\begin{array}{c}\text { ore } \\
\text { weight, } g\end{array}$ & $\begin{array}{c}\text { rock } \\
\text { weight, } g\end{array}$ & $\begin{array}{c}\text { ore } \\
\text { weight, } \mathrm{g}\end{array}$ \\
\hline \multirow[t]{7}{*}{$1^{\mathrm{st}}$} & 1 & 0 & 200 & 0 & 200 & 0 & 200 \\
\hline & 2 & 53 & 147 & 65 & 135 & 47 & 153 \\
\hline & 3 & 88 & 112 & 78 & 122 & 88 & 112 \\
\hline & 4 & 127 & 73 & 105 & 95 & 112 & 88 \\
\hline & 5 & 128 & 72 & 118 & 82 & 128 & 72 \\
\hline & 6 & 148 & 52 & 145 & 55 & 128 & 72 \\
\hline & 7 & 150 & 50 & 165 & 45 & 145 & 55 \\
\hline Total & - & 694 & 706 & 666 & 734 & 648 & 752 \\
\hline \multirow[t]{6}{*}{$2^{\text {nd }}$} & 1 & 0 & 200 & 0 & 200 & 0 & 200 \\
\hline & 2 & 63 & 137 & 30 & 170 & 38 & 162 \\
\hline & 3 & 100 & 100 & 92 & 108 & 70 & 130 \\
\hline & 4 & 135 & 65 & 132 & 68 & 105 & 95 \\
\hline & 5 & 148 & 52 & 148 & 52 & 143 & 57 \\
\hline & 6 & 150 & 50 & 155 & 45 & 146 & 54 \\
\hline Total & - & 596 & 604 & 557 & 634 & 502 & 698 \\
\hline \multirow[t]{6}{*}{$3^{\text {rd }}$} & 1 & 0 & 200 & 0 & 200 & 0 & 200 \\
\hline & 2 & 28 & 172 & 28 & 172 & 23 & 177 \\
\hline & 3 & 60 & 120 & 67 & 133 & 72 & 128 \\
\hline & 4 & 108 & 92 & 98 & 102 & 100 & 100 \\
\hline & 5 & 143 & 57 & 132 & 68 & 135 & 65 \\
\hline & 6 & 150 & 50 & 152 & 48 & 147 & 53 \\
\hline Total & - & 308 & 492 & 309 & 491 & 308 & 492 \\
\hline \multirow[t]{4}{*}{$4^{\text {th }}$} & 1 & 0 & 200 & 0 & 200 & 0 & 200 \\
\hline & 2 & 50 & 150 & 55 & 145 & 53 & 147 \\
\hline & 3 & 110 & 90 & 107 & 93 & 105 & 95 \\
\hline & 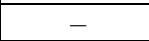 & 148 & 52 & 147 & 53 & 150 & 50 \\
\hline Total & $\begin{array}{llll}- & & & \\
-\end{array}$ & 308 & 492 & 309 & 491491 & 308 & 492 \\
\hline Total, g & - & 2107 & 2493 & 2009 & 2591 & 1935 & 2665 \\
\hline$\% \%$ & - & 45.8 & 54.2 & 43.7 & 56.3 & 42.1 & 57.9 \\
\hline
\end{tabular}


The rock mass drawing from the model is specified by the following:

- at the $1^{\text {st }}$ caving step abut the working, there was no side contact with the rock, conditions for ore sliding outside the caving zone were perfect. $75 \%$ ore dilution in the last doze increased with $1400 \mathrm{~g}$ drawing;

- on the contrary, at the $4^{\text {th }}$ caving step, there was a contact with perfect ore sliding at the abut plane of the working. That is why, the ore came into motion at the beginning of the drawing and ore dilution increased up to $75 \%$ with $800 \mathrm{~g}$ drawing. There were no conditions to create a durable ellipsoid of ore drawing.

Table 5 presents research results of the dependency of ore losses on localization of the soil of ore draw points.

Table 5. Ore losses in abut ore drawing, \%.

\begin{tabular}{|c|c|c|c|}
\hline \multirow{2}{*}{ Caving step } & \multicolumn{3}{|c|}{ Slope angle of the draw point, degree } \\
\cline { 2 - 4 } & 0 & 5 & 10 \\
\hline $1^{\text {st }}$ & 50.4 & 52.4 & 53.7 \\
\hline $2^{\text {nd }}$ & 50.3 & 53.6 & 57.6 \\
\hline $3^{\text {rd }}$ & 57.6 & 60.2 & 60.3 \\
\hline $4^{\text {th }}$ & 61.5 & 61.4 & 61.5 \\
\hline
\end{tabular}

With the $10^{\circ}$ draw point, ore losses were by $5 \%$ less as compared to the horizontal surface of the working.

The research results are matched with those by foreign and national mining scholars [13 - 16]. The data on development mining before stoping can be used while improving underground mining technologies $[17-20]$.

\section{Conclusions}

Improvement of development mining before stoping by means of access ramps is an efficient method of providing the designed mine capacity and labour efficiency.

The most widely spread schemes include the following: an access ramp between ore bodies on the one flank and a hoister on the other; an access ramp between ore bodies with stoping moving from the one flank to the other and two hoisters on both flanks.

Efficient parameters of development mining are chosen through simulating according to the criterion of ore losses and dilution chiefly.

The authors are grateful to Professor Kondrat'ev Yu.I., "The North Caucasian Mining and Metallurgical Institute (State Technological University)", for valuable comments in writing this article and discussing the obtained results.

\section{References}

1. Golik, V., Komashchenko, V., \& Morkun, V. (2015). Feasibility of using the mill tailings for preparation of self-hardening mixtures. Metallurgical and Mining Industry, (3), 38-41.

2. Golik, V., Komashchenko, V., \& Morkun, V. (2015). Innovative technologies of metal extraction from the ore processing mill tailings and their integrated use. Metallurgical and Mining Industry, (3), 49-52.

3. Kaplunov, D., Rylnikova, M., \& Radchenko, D. (2015). Problema ispolzovaniya vozobnovlyaemykh istochnikov energii v khode razrabotki mestorozhdeniy tverdykh poleznykh iskopayemykh. Fiziko-tekhnicheskie problemy razrabotki poleznykh iskopayemykh, (1), 88-96.

4. Neverov, A. (2014). Geomekhanicheskaya otsenka kombinirovannoy geotekhnologii pri otrabotke moshchnoy pologoy rudnoy zalezhi. Fiziko-tekhnicheskie problemy razrabotki 
poleznykh iskopayemykh, (1), 119-132.

5. Golik, V., Komashchenko, V., \& Kachurin, N. (2015). Kontseptsiya kombinirovaniya tekhnolohiy razrabotki rudnykh mestorozhdeniy. Izvestiya Tul'skogo gosudarstvennogo universiteta, (4), 76-88.

6. Golik, V., Komashchenko, V., Morkun, V., \& Zaalishvili, V. (2015). Enhancement of lost ore production efficiency by usage of canopies. Metallurgical and Mining Industry, (4), 325-329.

7. Morkun, V., Morkun, N., \& Pikilnyak, A. (2015). Adaptive control system of ore beneficiation process based on Kaczmarz projection algorithm. Metallurgical and Mining Industry, (2). 35-38.

8. Golik, V.I., Polukhin, O.N., Petin, A.N., Komashchenko, V.I. (2013). Ekolohicheskiye problemy razrabotki rudnykh mestorozhdeniy KMA. Gornyy zhurnal, (4), 91-94.

9. Morkun, V., Morkun, N., \& Pikilnyak, A. (2014). The gas bubble size distribution control formation in the flotation process. Metallurgical and Mining Industry, (4), 42-45.

10. Golik, V., Komaschenko, V., Morkun, V., \& Khasheva, Z. (2015). The effectiveness of combining the stages of ore fields development. Metallurgical and Mining Industry, (5), 401-405.

11. Golik, V., Komashchenko, V., \& Morkun, V. (2015). Geomechanical terms of use of the mill tailings for preparation. Metallurgical and Mining Industry, (4), 321-324.

12. Golik, V., Komaschenko, V., Morkun, V., \& Burdzieva, O. (2015). Metal deposits combined development experience. Metallurgical and Mining Industry, (6), 591-594.

13. Morkun, V., Morkun, N., \& Pikilnyak, A. (2014). Iron ore flotation process control and optimization using high-energy ultrasound. Metallurgical and Mining Industry, (2), 36-42.

14. Golik, V., Komashchenko, V., Morkun, V., \& Burdzieva, O. (2016). Simulation of rock massif tension at ore underground mining. Metallurgical and Mining Industry, (7), 76-79.

15. Haifeng, W., Yaqun, H., Chenlong, D., Yuemin, Z., Youjun, T. \& Cuiling, Y. (2012). Development of Mineral Processing Engineering Education in China University of Mining and Technology. Advances in Computer Science and Engineering, 77-83.

16. Bakhtavar, E., \& Shahriar, K. (2007). Optimal ultimate pit depth considering an underground alternative. Proceedings of Fourth Aachen International Mining Symposia-High Performance Mine Production, 213-221.

17. Golik, V.I., Razorenov, Y.I., Ignatov, V.N., Khasheva, Z.M., \& Shulgaty, L.P. (2016). The History of Russian Caucasus Ore Deposit Development. The Social Sciences, 11(15), 3742-3746.

18. Dmitrak, Y., \& Kamnev, Y. (2016). Vedushchiy proektno-izyskatelskiy i nauchno-issledovatelskiy institut promyshlennoy tekhnologii. Put' dlinoy v 65 let. Gornyy zhurnal, (3), 6-12.

19. Kachurin, N., Stas, G., Kalaev, S., \& Korchagina, T. (2016). Geoecological assessment of the effectiveness of environmental and nature protection measures in under the earth. Mining coal. The Bulletin of Tula State University. Earth Sciences, (3), 63-81.

20. Kachurin, N., Stas, G., Levin, D., \& Fisher, W. (2016). Aerodynamics of waste dumps of coal mines. The Bulletin of Tula State University. Earth Sciences, (1), 23-33. 